\title{
EFFECT OF POLIOMYELITIS ON SODIUM AND POTASSIUM IN SERUM AND URINE
}

\author{
BY \\ M. DIWANI, M. TALAAT, Y. A. RAHMAAN and A. SAMY KHALIFA \\ From the University Children's Hospital, Mounira, Cairo, Egypt
}

(RECEIVED FOR PUBLICATION MAY 9, 1962)

Poliomyelitis is a problem receiving increasing attention in this country. Although this disease is as old as ancient Egypt, its importance has only been recently recognized and before the middle of this century no significant study of the disease had been carried out. Statistical surveys (Paul, Havens and Van Rooyen, 1944; Paul, 1949; Khalil, Ragab and Sakr, 1954; Gilliam, Hemphill and Gerende, 1949; Khalil and Abdin, 1954), and estimations of antibody titres (Paul, Melnick, Barnett and Goldblum, 1952; Paul, Melnick and Riordan, 1952; Williamson, 1957) appeared in the 1940s, but the only virological and clinical study of poliomyelitis was carried out in 1960 (Hashem, Akers and Mahdy, 1960). These studies of poliomyelitis, however, did not cover all aspects of the disease and there has been no report in this country regarding the electrolyte disturbances that accompany different types of the disease.

The present work is an attempt to assess the electrolyte disturbances in poliomyelitis as observed in Egypt, with particular reference to the changes in sodium and potassium as the two main electrolytes of the body. In order to do this correctly, normal standards for sodium and potassium both in serum and urine had to be obtained.

The age-groups of normal children covered by the present work extended from birth to the age of 12 years. Although poliomyelitis is very rare above 8 years, four extra years were included as a safety margin for the study. The age-group over 12 years was not considered.

\section{Variability of Sodium and Potassium with Age and Sex}

Sodium. The serum sodium in newborn infants, growing children, healthy young adults, and old men and women, were reported by Danowski et al. (unpublished data) to be as follows:

For the newborn, $143 \pm 3.3 \mathrm{mEq} / 1$; growing children, $144 \pm 3 \mathrm{mEq} / \mathrm{l}$; young adults, $146 \pm$
$2.6 \mathrm{mEq} / \mathrm{l}$; and old men and women, $144 \pm 3 \cdot 2$ $\mathrm{mEq} / \mathrm{l}$.

The daily urinary excretion in normal adults was found by Weisberg (1953) to be $111 \mathrm{mEq} / 24$ hours or $40-90 \mathrm{mEq} / \mathrm{l}$. The scatter was found to be greatest in the newborn infants, but sodium levels as low as 136 were only rarely encountered irrespective of age (Danowski et al., unpublished data). According to Smith (1959) the sodium concentration in serum of newborn infants is not significantly different from the normal range in adult serum. Cord blood serum, on the other hand, has been reported to contain the same amount as maternal blood (Overman, Etteldorf, Bass and Horn, 1951), a little less (Hoag and Kiser, 1931), and a little more (Miller, 1941).

Potassium. Newborn infants may have distinctly high serum potassium values. Beyond infancy the range narrows with an upper limit of 5.6 or 5.8 $\mathrm{mEq} / \mathrm{l}$. Danowski et al. (unpublished data) gave the following values for serum potassium.

For the newborn, $5.9 \pm 1.4 \mathrm{mEq} / \mathrm{l}$; growing children, $4.3 \pm 0.4 \mathrm{mEq} / 1$; ; young adults, $4.4 \pm$ $0.3 \mathrm{mEq} / \mathrm{l}$; ; and old men and women, $4.6 \pm 0.4$ $\mathrm{mEq} / \mathrm{l}$.

The urinary excretion in normal adults varies between 20-60 mEq/l. (Weisberg, 1953).

Some increase in serum potassium content was found at birth or on the first day by Edelstein and Ylppö (1921); Bakwin and Rivkin (1927); McCance and Young (1941), and Strengers, Maas, Rottinghuis and Fehmers (1954). Österlund (1955) and Overman et al. (1951) found that the mean umbilical cord plasma potassium was some $20 \%$ more than that on the maternal side of the placenta.

Widdowson and McCance (1956) have suggested that foetal cells may be less able than adult cells 'to take in potassium against a high concentration gradient'.

Diwani, Waly, Mazni and Mouktar (1959), studying blood chemistry in diarrhoeal disease in 
Egypt, found the average normal levels of sodium in the blood of 21 infants within the first two years of life to be $143.96 \mathrm{mEq} / \mathrm{l}$. with a range from 132.5 to $158 \mathrm{mEq} / 1$., and of potassium $5.4 \mathrm{mEq} / \mathrm{l}$. with a range from 4.38 to $7.04 \mathrm{mEq} / \mathrm{l}$.

\section{Changes in Sodium and Potassium in Poliomyelitis}

Astrup, Gøtzche and Neukirch (1954) and Plum and Wolff (1951) studied the effects of respiratory inefficiency in poliomyelitis. In patients who have poliomyelitis with bulbar or bulbo-spinal involvement, the control of respiratory gas exchange is usually impaired, resulting in severe hypoxia and carbon dioxide retention. Hypoxia results in damage to the central nervous system, increased capillary permeability, pulmonary oedema and cardiovascular collapse. High levels of carbon dioxide (hypercapnia) result from inadequate alveolar elimination and lead to respiratory acidosis with stimulation, followed by depression of the respiratory centre and vascular collapse. These effects of hypoxia and carbon dioxide retention may further interfere with respiratory gas exchange or intensify the severity of an acute illness. Although the respirator (iron lung) may be life saving, it will cause wide fluctuation in respiratory gas exchange. Overventilation alkalosis commonly occurs, while acute carbon dioxide retention may sometimes take place due to episodes of respiratory obstruction resulting from retained secretions and tracheal plugs.

The variations in blood gases and in the hydrogen ion concentration accompanying the above events have been observed. On the other hand, only a few attempts have been made to study the changes in electrolytes, particularly sodium and potassium. In poliomyelitis a redistribution of sodium and potassium over the different phases of body fluids has been reported. Serum sodium was found to be diminished by Thomson (1957), Jungner (1958) and Astrup et al. (1954). Chudnoff (1954) found normal initial values of serum sodium, which fell below normal after adequate hydration. Allott (1957), on the other hand, reported inconsistent results. The urinary sodium levels have been found to be low by all these workers.

In the case of potassium, it is generally accepted that low potassium levels with a corresponding high urinary excretion are found particularly in acute poliomyelitis. Astrup et al. (1954) found normal serum values in the majority of cases, hypokalaemia in some and hyperkalaemia in others with azotaemia. Bower, Morgan and Chaney (1952), Gemzell (1956) and Earle (1950) reported low serum potassium levels. Lans, Stein, Becker, Hoyne and Meyer (1951) emphasized the importance of potassium deficiency in poliomyelitis, and reported clinical improvement after its administration. Hall and Sherman (1953) ascribed potassium depletion to lack of intake due to anorexia and difficult swallowing. Lack of absorption due to gastro-intestinal atony may aggravate the failure to maintain a normal potassium level.

Jungner (1958) and Chudnoff (1954) found initial high normal, or a raised level, of serum potassium followed by a fall. The urinary potassium values were found to be high relative to the intake and greater than urinary sodium excretion.

Previous investigators have not reported on the degree of urinary excretion or the plasma levels of sodium or potassium in relation to the phases or the different types of the disease. Nor have they compared the potassium or sodium levels in poliomyelitis patients with the levels of normal controls. For instance, a potassium level of $3.9 \mathrm{mEq} / \mathrm{l}$. was considered by Lans et al. (1951) to be hypokalaemia, necessitating therapeutic measures.

\section{Material and Method}

In the cases reported here the sodium and potassium both in serum and urine were estimated by flame photometry.

Three groups of children were studied: Group 1 consisting of normal children, Group II of poliomyelitis cases with respiratory involvement, and Group III of poliomyelitis cases without respiratory involvement.

Group I: Normal. To obtain serum values of sodium and potassium, samples were obtained from normal infants and children over the age-group 0-12 years. The age-groups were classified in the following way:

(i) immediately after birth, i.e. cord blood,

(ii) the neonatal period, i.e. the first month of life,

(iii) from 1 to 6 months, (iv) from 6 months to

the end of the first year, (v) from 1 to 2 years,

(vi) from 2 to 5 years, and (vii) from 5 to 12 years.

The infants and children were put on an ordinary diet. The children were chosen for their normal good health, weight and development. Blood samples were taken after a night's fast, using a dry syringe and wide-bore dry needle to avoid haemolysis, and received into a dry centrifuge tube and left to clot. The tube was centrifuged at 2,500 r.p.m. for 15 minutes and the serum withdrawn at once, using a dry glass pipette. Serum was diluted 1:100 in distilled water and atomized in the flame. Serum is preferred to whole blood or plasma as it is more or less of a constant composition. Anticoagulants used in the preparation of plasma interfere greatly with its electrolyte content.

For the determination of urinary sodium and potassium, morning samples after a night fast were chosen as 24-hour samples were found impractical, particularly in respirator cases. Catheterization was done if necessary. Urine was diluted $1: 100$ and atomized in the same way as the serum. 


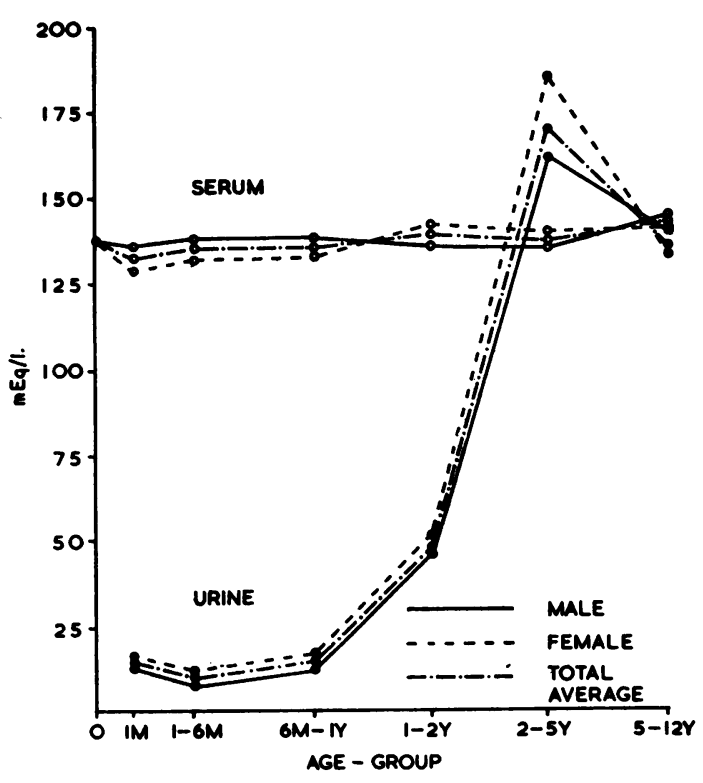

Fig. 1.-Variations of sodium in serum and urine over the various age-groups.

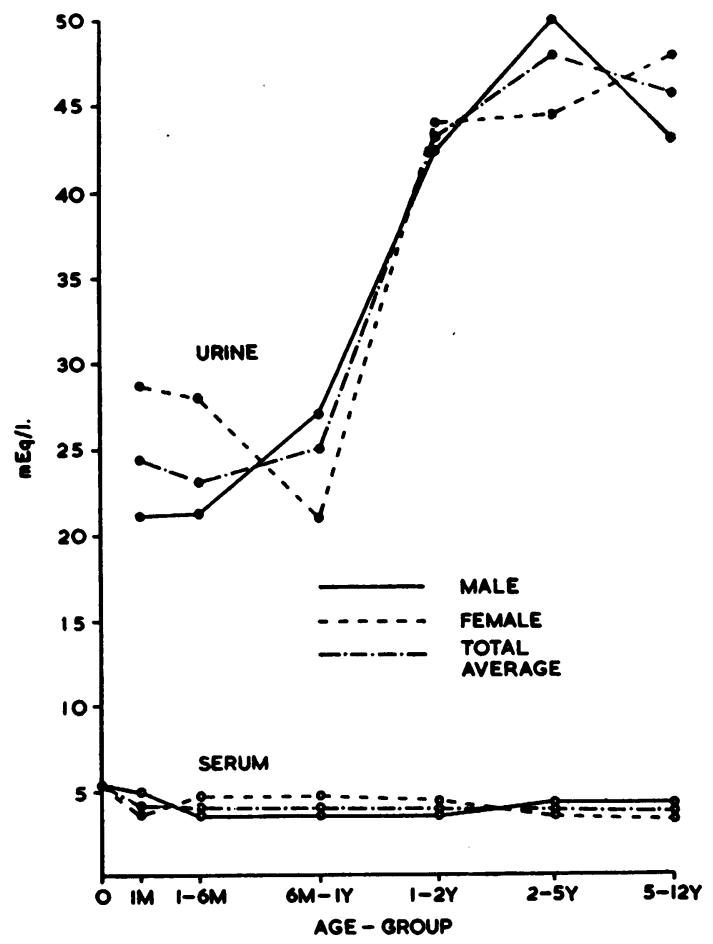

Fig, 2.-Variations of potassium in serum and urine over the various age-groups.
Group II: Poliomyelitis Cases with Respiratory Involvement. Twenty-two cases needing respirator therapy were examined on admission and subjected to serum and urine analysis, for both sodium and potassium, and weekly afterwards to include the acute catabolic, subacute catabolic and the anabolic phases of the disease.

These cases showed respiratory paralysis, either intercostal, diaphragmatic or both. The cases usually manifested spinal paralysis other than the respiratory muscles in the form of limb, trunk or neck affection. Pharyngeal paralysis, facial nerve palsy or squint were present in some cases due to cranial nerve involvement. The respirator used was the tank type with negative pressure of $15 \mathrm{~cm}$. water to zero pressure or slight positivity. Positive pressure method using the hood was only occasionally used during infusions or physiotherapy when the cabin was opened. The period of stay in the apparatus varied from a few days to a few weeks. Diet was given by gavage in the first days of respirator therapy to overcome underfeeding from difficulty in swallowing and anorexia.

Group III: Poliomyelitis Cases with No Respiratory Involvement. Ten cases of poliomyelitis were studied. The cases were acute or chronic with one or several limbs affected, but with no respiratory involvement at any phase of the disease.

\section{Results}

The changes in the values of sodium and potassium in serum and urine in the various age-groups in normal children are represented in Figs. 1 and 2. The mean values for serum potassium were highest in cord blood samples $(5.45 \mathrm{mEq} / \mathrm{l}$.) and diminished gradually with increasing age, being $4.8 \mathrm{mEq} / \mathrm{l}$. in the first month, $4.4 \mathrm{mEq} / 1$. from 1 to 6 months, $4.25 \mathrm{mEq} / 1$. from 6 months to 1 year, $4.41 \mathrm{mEq} / 1$. from 1 to 2 years, $4 \cdot 16 \mathrm{mEq} / 1$. from 2 to 5 years, and $4.05 \mathrm{mEq} / \mathrm{l}$. from 5 to 12 years. Slight male preponderance was noticed in infants under 1 month, and in the age-group 2-5 and 5-12 years. Female preponderance was noticed in all age-groups from 1 month to 2 years. The variation between male and female values ranged between 0.08 and $0.58 \mathrm{mEq} / \mathrm{l}$.

Infants excreted urine containing small amounts of potassium, the average being $24 \mathrm{mEq} / 1$. in the neonatal period, $22.7 \mathrm{mEq} / 1$. from 1 to 6 months, and $25 \mathrm{mEq} / 1$. from 6 months to 1 year. In the older age-groups there was a marked rise in urinary potassium; $43 \mathrm{mEq} / 1$. from 1 to 2 years, $48 \cdot 1 \mathrm{mEq} / 1$. from 2 to 5 years and $45.5 \mathrm{mEq} / 1$. from 5 to 12 years. Values for girls predominate in all agegroups except in the 2 to 5 year age-group. The variation between male and female values ranged between 0.9 and $7.9 \mathrm{mEq} / 1$.

Average serum sodium levels were found to be lowest in the younger age-groups: $135.3 \mathrm{mEq} / \mathrm{l}$. in cord blood samples, 132.8 in the first month, $135.9 \mathrm{mEq} / 1$. from 1 to 6 months, and $136.3 \mathrm{mEq} / \mathrm{l}$. 
from 6 months to 1 year. The average level then rose gradually through childhood; $139.4 \mathrm{mEq} / \mathrm{l}$. from 1 to 2 years, $138.6 \mathrm{mEq} / \mathrm{l}$. from 3 to 5 years, and $142 \cdot 5 \mathrm{mEq} / \mathrm{l}$. from $5-12$ years. Male values were higher in the neonatal, 1 to 6 months, 6 months to 1 year, and 5 to 12 year groups. The variation between male and female values ranged between 1.9 and $5.6 \mathrm{mEq} / \mathrm{l}$.

Mean urinary sodium levels were least in the younger age-groups: $15.4 \mathrm{mEq} / \mathrm{l}$. in the neonatal period, $11 \cdot 3 \mathrm{mEq} / \mathrm{l}$. from 1 to 6 months, $17 \mathrm{mEq} / 1$. from 6 months to 1 year. A marked rise occurred after the first year with average values of $49 \mathrm{mEq} / \mathrm{l}$. from 1 to 2 years, 169.4 from $2-5$ years and 136.9 $\mathrm{mEq} / \mathrm{l}$. in the 5 to 12 year age-group. The females predominated in all groups except from 5 to 12 years. The variation between male and female values ranged between 0.7 and $21.5 \mathrm{mEq} / 1$.

The average levels of serum and urinary sodium and potassium in the various stages of poliomyelitis with respiratory involvement are given in Table 1 and Figs. 3 and 4 . From these it will be seen that in the first week of the disease there was a transient rise in serum potassium and a diminution of urinary potassium, while there was a slightly low serum sodium level and a markedly diminished urinary sodium excretion. The serum potassium fell to a minimum in the third week, preceded by a marked rise in urinary potassium excretion in the second week. The raised potassium level during the first week was most marked in the more severe respiratory cases. There was a gradual rise in serum potassium from the third week, which reached normal levels in the fourth week.

In the cases of poliomyelitis with no respiratory involvement, the transient rise in serum potassium was not manifest, the level not exceeding $4.9 \mathrm{mEq} / 1$; the diminution in the third week was not as marked as in respiratory cases. More or less normal serum potassium levels were observed (average $4.3 \mathrm{mEq} / 1$.) in the third week. The average sodium in serum in the first week $(131 \mathrm{mEq} / \mathrm{l}$.) rose gradually during the following weeks to $142 \mathrm{mEq} / \mathrm{l}$. in the third week.

TABLE 1

POLIOMYELITIS CASES WITH RESPIRATORY INVOLVEMENT: AVERAGES OF SERUM AND URINARY SODIUM AND POTASSIUM

\begin{tabular}{|c|c|c|c|c|}
\hline \multirow{2}{*}{$\begin{array}{c}\text { Duration of Disease } \\
\text { (weeks) }\end{array}$} & \multicolumn{2}{|c|}{ Serum } & \multicolumn{2}{|c|}{ Urine } \\
\hline & $\underset{(\mathrm{mEq} / \mathrm{l} .)}{\mathrm{Na}}$ & $\underset{(\mathrm{mEq} / 1 .)}{\mathrm{K}}$ & $\underset{(\mathrm{mEq} / \mathrm{l} .)}{\mathrm{Na}}$ & $\underset{(\mathrm{mEq} / \mathrm{l} .)}{\mathrm{K}}$ \\
\hline $\begin{array}{r}1 \\
2 \\
3 \\
4 \\
>4\end{array}$ & $\begin{array}{l}133 \cdot 9 \\
135 \cdot 8 \\
136 \\
136 \\
138 \cdot 5\end{array}$ & $\begin{array}{l}5 \cdot 9 \\
4 \cdot 6 \\
3 \cdot 8 \\
4 \cdot 1 \\
4 \cdot 28\end{array}$ & $\begin{array}{c}62 \cdot 8 \\
97 \\
92 \cdot 5 \\
125 \\
92 \cdot 5\end{array}$ & $\begin{array}{l}24 \cdot 6 \\
70 \cdot 5 \\
49 \cdot 7 \\
42 \cdot 7 \\
48 \cdot 5\end{array}$ \\
\hline
\end{tabular}

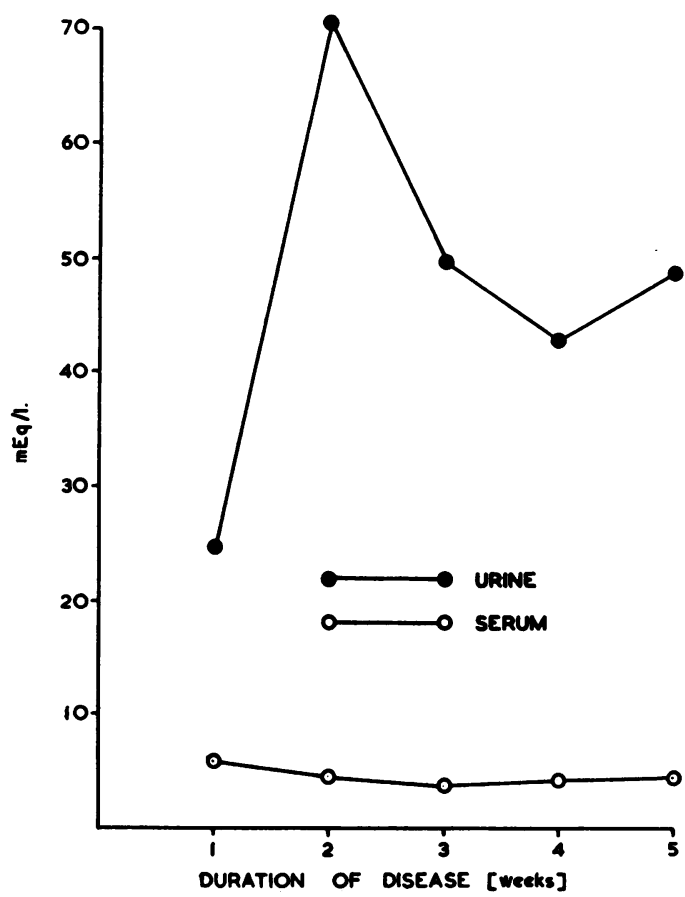

FIG. 3.-Variations of serum and urinary potassium with respiratory poliomyelitis.

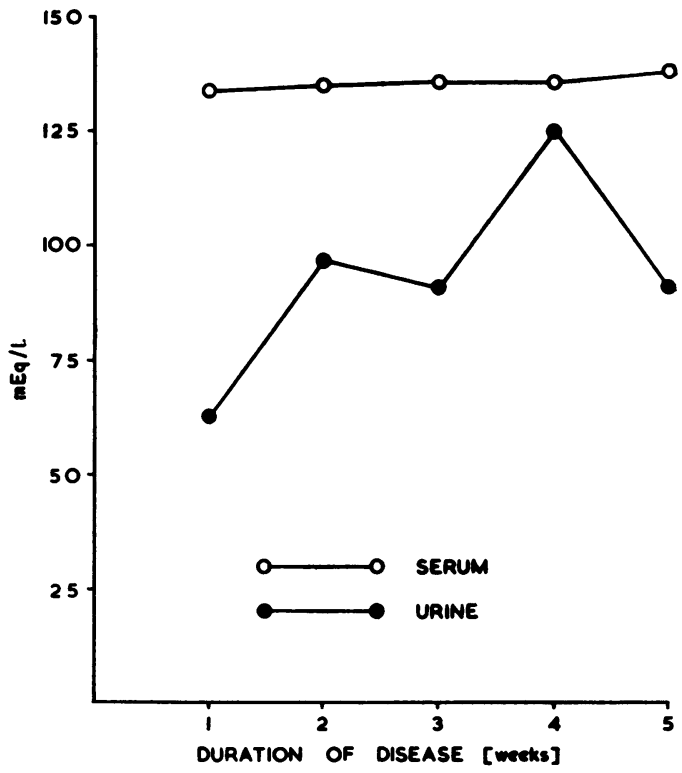

FIG. 4.-Variations of serum and urinary sodium with respiratory poliomyelitis. 
However, old poliomyelitis cases with contractures, showed low normal sodium values (average 134.4 $\mathrm{mEq} / \mathrm{l}$.).

In those cases without respiratory involvement the urinary sodium was low (average $39 \mathrm{mEq} / \mathrm{l}$.) in the first week, and the rise in the urinary sodium to normal levels was conspicuous from the second week of the disease onwards, the average being $85 \mathrm{mEq} / \mathrm{l}$. in the second week. The urinary potassium also rose in the second week to an average of $104 \mathrm{mEq} / \mathrm{l}$. and dropped back to average normal values of $55 \mathrm{mEq} / \mathrm{l}$. after the second week. These findings are comparable in magnitude to those in the cases with respiratory paralysis as far as urinary changes and serum sodium are concerned. On the other hand the changes in serum potassium are much smaller than in the group with respiratory involvement.

\section{Discussion}

Normal Values for Serum and Urinary Sodium and Potassium. The normal serum potassium was found to vary between $4 \cdot 04-5.45 \mathrm{mEq} / \mathrm{l}$., being highest in cord blood samples and diminishing gradually through the following age-groups. The high level in cord blood may explain in part the hyperexcitability noticed in the first few days of postnatal life. The high cord blood levels and the relatively high values in the first few days of life agree with other investigators (Overman et al., 1951; Edelstein and Ylppö, 1921; Bakwin and Rivkin, 1927; McCance and Young, 1941; Strengers et al., 1954; Österlund, 1955). Relative hypofunction of the parathyroid glands is the most generally accepted theory (Crosse, 1961). The sex difference in serum potassium varied between 0.08 and $0.58 \mathrm{mEq} / 1$. These values agree with those of other investigators: 4-5.5 (Hansen, 1959), 3.6-5 (Boyd, 1958), 3.2-5.8 (Elkinton and Danowski, 1955), $4 \cdot 3 \pm 0.4$ (Danowski et al., unpublished data). These levels, however, approach the lower normal values of Diwani et al. (1959) $(4 \cdot 38 \mathrm{mEq} / \mathrm{l}$.).

On the other hand, infants excrete urine containing small amounts of potassium $(22 \cdot 7-25 \mathrm{mEq} / 1$.). There is a rise in urinary potassium in the older agegroups, being 43 in the age-group 1 to 2 years, 48.1 in the age-group 2 to 5 years, and 45.5 in the age-group 5 to 12 years. These values agree with those already reported $(20-60 \mathrm{mEq} / \mathrm{l}$., Weisberg, 1953). The sudden rise of urinary potassium from the first year onwards may be explained by the fact that weaning is usually started at that age in Egypt, with the administration of foods rich in potassium, especially fruits and vegetables.

Serum sodium varies between $132.8 \mathrm{mEq} / \mathrm{l}$. in the neonatal period and then rises gradually to reach
$142.5 \mathrm{mEq} / \mathrm{l}$. in the age-group 5 to 12 years. The cord blood value was found to be $135 \cdot 3 \mathrm{mEq} / \mathrm{l}$. These values lie in the range obtained by previous investigators: 142 (Hansen, 1959), 135-155 (Boyd, 1958), 137-147 (Weisberg, 1953), $143 \pm 3 \cdot 3$ (Danowski et al., unpublished data), 132.5-158 mEq/l. (Diwani et al., 1959), and agree with those reported (Smith, 1959; Overman et al., 1951; Hoag and Kiser, 1931; Miller, 1941).

Urinary sodium is minimal in the younger agegroups, the average being $15.4 \mathrm{mEq} / \mathrm{l}$. A marked rise occurs from the 1 to 2 year age-group onwards, reaching values as high as $169.4 \mathrm{mEq} / \mathrm{l}$. in the 2 to 5 year age-group.

The sudden rise in urinary sodium also coincides with the onset of weaning and the administration of diet rich in salts. The relatively hypotonic urine in the neonatal period and early infancy agrees with the finding reported previously (McCance and Young, 1941). This may be ascribed to the fact that the kidney of the very young infant is a relatively ineffective organ. The sodium values in urine reported in the present work are relatively higher than those in the literature, the latter being $40-90 \mathrm{mEq} / \mathrm{l}$. (Weisberg, 1953). This is largely due to the differences in dietary habits in Egypt and elsewhere.

Changes in Poliomyelitis Cases with Respiratory Involvement. The majority of these cases (14, i.e. $63 \%$ ) showed increases in serum potassium to levels varying from $4 \cdot 6$ to $7 \cdot 1 \mathrm{mEq} / \mathrm{l}$. The cases showing the most marked rise were among the severest, five of them $(35 \%)$ died within the first week of the disease with respiratory insufficiency, circulatory collapse or hyperthermia, due to affection of the higher centres. Five cases of the series studied $(23 \%)$ showed normal potassium levels at the first examination, while the remaining three cases $(14 \%)$ showed levels below the average for their standard. These low levels may be ascribed to late sampling after the first week of the disease in two of them. The serum potassium decreased to minimal levels during the third week of the disease. Only one case showed a level of 3.3 $\mathrm{mEq} / \mathrm{l}$. The cardiogram of this case reveals no changes suggesting hypokalaemia. The serum potassium returned to normal levels within the following 15 days.

The high initial levels may be due to one of the following causes: (1) stress reaction causing shift of the intracellular potassium to the extracellular compartment; (2) tissue destruction by the disease in the acute catabolic phase causing liberation of potassium from the cells; (3) acidosis due to 
inadequate gas exchange before respirator therapy. The subsequent low levels may be attributed to potassium loss by the kidney and inadequate replacement because of anorexia, nausea, vomiting and difficult swallowing. Lack of absorption from gastro-intestinal atony is probably also a factor. The cases investigated showed diminished urinary excretion of potassium during the transient rise in the serum level. This diminution did not exceed the lower normal limits. A marked rise in potassium excretion in urine was noticed before the period of low serum potassium. The initial raised serum potassium agrees with the findings reported by some workers (Jungner, 1958; Chudnoff, 1954; Bower et al., 1952). However, the absence of extremely low levels found by others (Astrup et al., 1954; Jungner, 1958; Chudnoff, 1954; Bower et al., 1952; Gemzell, 1956; Earle, 1950), may be ascribed to the adequate care offered to those cases and the maintenance of a good fluid supply, mainly fruit juices rich in potassium.

The changes in sodium are less conspicuous; there was a decrease in seven of the 14 cases presenting with high serum potassium levels. Values as low as $123.5 \mathrm{mEq} / \mathrm{l}$. were obtained. Normal or raised serum sodium levels were found in the remaining 14 cases with respiratory involvement, and bore no relation to potassium levels. This decrease in serum sodium may be explained by the fact that ionic transfer between the extracellular and intracellular compartments has taken place.

Cases showing low serum sodium attained normal levels by the second week. These findings are in conformity with those reported by other investigators (Thomson, 1957; Allott, 1957; Bower et al., 1952).

The cases studied showed a marked drop of urinary excretion of sodium; levels as low as $4 \mathrm{mEq} / \mathrm{l}$. were obtained. However, normal urinary levels were restored by the second week. These findings agree with those of other investigators (Allott, 1957; Bower et al., 1952).

Poliomyelitis Cases with No Respiratory Involvement. The changes in urinary sodium and potassium, as well as serum sodium in cases of poliomyelitis with no respiratory involvement, were similar to the corresponding changes for the cases with respiratory involvement. However, the changes in serum potassium were less conspicuous.

\section{Summary}

Normal standards for serum and urinary sodium and potassium were prepared for Egyptian infants between the ages of 0 and 12 years to include the age-groups most susceptible to poliomyelitis. The serum potassium varied between 4.05 and 5.45 and the serum sodium between 132.8 and $142.5 \mathrm{mEq} / \mathrm{l}$. The urinary levels of potassium and sodium showed marked rise with the start of weaning. Potassium excretion varied between $22 \cdot 7-48 \cdot 1 \mathrm{mEq} / 1$. and sodium $11 \cdot 3-169 \cdot 4 \mathrm{mEq} / \mathrm{l}$.

Severe cases of poliomyelitis with respiratory involvement showed an initial transient rise in serum potassium in the majority of cases, followed by a diminution, although not reaching severe hypopotassaemic levels, requiring therapy. The urinary potassium usually showed raised levels before the onset of low serum levels, denoting the role played by the kidney in its formation. On the other hand, serum sodium levels might decrease or remain normal during the initial period corresponding to the transient rise in serum potassium. During such a period urinary excretion of sodium usually diminished markedly to levels that were sometimes very low.

The severest cases of poliomyelitis were accompanied by the highest rise in serum potassium levels, so that the degree of serum potassium rise should give some idea of the severity and prognosis of the poliomyelitis cases.

Poliomyelitis cases with no respiratory involvement showed the same electrolyte changes as those with respiratory involvement, but the changes in serum potassium were of a milder degree.

\section{REFERENCES}

Allott, E. N. (1957). Hypernatraemia and hyperchloraemia in bulbar poliomyelitis. Lancet, 1, 246.

Astrup, P., Gøtzche, H. and Neukirch, F. (1954). Laboratory investigations during treatment of patients with poliomyelitis and respiratory paralysis. Brit. med. J., 1, 780 .

Bakwin, $H$. and Rivkin, $H$. (1927). A comparison of the content of potassium in maternal and placental serum. Amer. J. Obstet. Gynec., 13, 68.

Bower, A. G., Morgan, F. M. and Chaney, A. L. (1952). Nitrogen and potassium metabolism: the reaction pattern in poliomyelitis. Amer. J. med. Sci., 223, 532.

Boyd, W. (1958). Pathology for the Physician, 6th ed., p. 881. Lea and Febiger, Philadelphia.

Chudnoff, J. S. (1954). Biochemistry and electrolyte changes in poliomyelitis. In Diagnosis and Treatment of the Acute Phase of Poliomyelitis and its Complications, ed. Albert G. Bower, chap. 13, p. 176. Williams and Wilkins. Baltimore.

Crosse, V. M. (1961). The Premature Baby, 5th ed., chap. 7, p. 192. Churchill, London.

Danowski, T. S. et al. Unpublished data, quoted in Elkinton, J. R. and Danowski, T. S. (1955). The Body Fluids: Basic Physiology and Practical Therapeutics, pp. 119-24. Williams and Wilkins, and Practical

Diwani, M., Waly, G., Mazni, A. and Mouktar, N. (1959). Blood chemistry studies in diarrhoeal diseases. Gaz. Egypt. paediat. Ass., 7, 9.

Earle, A. M. (1950). Serum potassium in poliomyelitis. J. Pediat., 36, 715 .

Edelstein, F. and Ylppö, A. (1921). Übergang der sogenannten diffusiblen Serumsalze durch die Placenta von der Mutter auf diffusiblen Serumsalze durch die Place
das Kind. $Z$. Kinderheilk., 27, 79 .

Elkinton, J. R. and Danowski, T. S. (1955). The Body Fluids: Basic Physiology and Practical Therapeutics, p. 3. Williams and Wilkins, Baltimore.

Gemzell, C. A. (1956). Adrenal cortical activity of patients with poliomyelitis acuta. Acta med. scand., 154, Suppl. 316, p. 104.

Gilliam, A. G., Hemphill, F. M. and Gerende, J. H. (1949). Average poliomyelitis incidence reported in the counties of the United States, 1932-1946. Publ. Hlth Rep. (Wash.), 64, 1575. 
Hall, R. J. and Sherman, J. L. (1953). Significance of potassium depletion in poliomyelitis. Amer. J. Med., 14, 124.

Hansen, A. E. (1959). In Textbook of Pediatrics, ed. W. E. Nelson, 7th ed., p. 105. Saunders, Philadelphia.

Hashem, N., Akers, T. G. and Mahdy, S. (1960). Studies on paralytic poliomyelitis in Cairo. NAMRU Res. Reports MR005.091202.2.01 and MR005.09.02.02.

Hoag, L. A. and Kiser, W. H., Jr. (1931). Acid-base equilibrium of new-born infants. I. Normal standards. Amer. J. Dis. Child., 41, 1054.

Jungner, I. (1958). Biochemical changes in poliomyelitis patients. In Poliomyelitis: Papers and Discussions presented at the Fourth International Poliomyelitis Conference, p. 530. Lippincott, Philadelphia.

Khalil, A., Ragab, M. M. and Sakr, R. (1954). Incidence of poliomyelitis in Egypt. Gaz. Egypt. paediat. Ass., 2, 200.

Khalil, A. K. and Abdin, Z. H. (1954). Some aspects of poliomyelitis in Egypt. A contribution to the study of polio. Gaz. Kasr-ElAiny Fac. Med., 1 and 2, 1.

Lans, H. S., Stein, I. F., Becker, R. J., Hoyne, A. L. and Meyer, K. A. (1951). Potassium deficiency in bulbar poliomyelitis. J. Amer. med. Ass. 146, 1017.

McCance, R. A. and Young, W. F. (1941). The secretion of urine by newborn infants. J. Physiol. (Lond.), 99, 265.

Miller, R. A. (1941). Shock in the newborn infants. Arch. Dis. Childh., 16, 230.

Osterlund, K. (1955). A Comparative Investigation of the Concentration of Certain Electrolytes in Maternal and Cord Blood. Ann. Paediat. Fenn., 1, suppl. 4.
Overman, R. R., Etteldorf, J. N., Bass, A. C. and Horn, G. B. (1951). Plasma and erythrocyte chemistry of the normal infant from birth to two years of age. Pediatrics, 7,565 .

Paul, J. R. (1949). Poliomyelitis attack rates in American troops, 1940-1948. Amer. J. Hyg., 50, 57.

- Havens, W. P., Jr. and Van Rooyen, C. E. (1944). Poliomyelitis in British and American troops in the Middle East. Brit. med. J., 1, 841 .

-, Melnick, J. L., Barnett, V. H. and Goldblum, N. (1952). A survey of neutralizing antibodies to poliomyelitis virus in Cairo, Egypt. Amer. J. Hyg., 55, 402.

- - and Riordan, J. T. (1952). Comparative neutralizing antibody patterns to Lansing (type 2) poliomyelitis virus in different populations. ibid., 56, 232.

Plum, F. and Wolff, H. G. (1951). Observations on acute poliomyelitis with respiratory insufficiency. J. Amer. med. Ass., 146, 442.

Smith, C. A. (1959). The Physiology of the Newborn Infant, 3rd ed., pp. 354-5. Blackwell, Oxford.

Strengers, T., Maas, J. W., Rottinghuis, H. and Fehmers, G. A. (1954). Plasma electrolytes in the neonatal period. Acta paediat. (Uppsala), 43, 342.

Thomson, A. E. (1957). Electrolyte studies in the respiratory paralysis of poliomyelitis. Amer. J. Med., $22,549$.

Weisberg, H. F. (1953). Water, Electrolyte and Acid-base Balance, pp. 29-47. Williams and Wilkins, Baltimore

Widdowson, E. M and McCance, R. A. (1956). The effect of development on the composition of the serum and extracellular fluids. Clin. Sci., 15, 361 .

Williamson, B. (1957). Poliomyelitis. In A Handbook on Diseases of Children, 8th ed., p. 309. Livingstone, Edinburgh. 